\title{
A CELLULAR AUTOMATA MODEL FOR MONITORING AND SIMULATING URBAN LAND USE/COVER CHANGES TOWARD SUSTAINABILITY
}

\author{
Ali KHATIBI, Sharareh POUREBRAHIM*, Afshin DANEHKAR \\ Department of Environmental Science, Faculty of Natural Resources, University of Tehran, Iran
}

Received 20 August 2016; accepted 17 January 2017

\begin{abstract}
This study presents an integrated model based on cellular automata for assessing and simulating land use/cover changes and their impact on the environment. Satellite images from Landsat TM and ETM + sensors from the time period of 1985 to 2014 were applied. Seven static and five dynamic variables were applied. These included elevation, slope, aspect, soil salinity, soil texture, distance from rivers, and roads, and distance from the five classes of land use. The model was validated by a fuzzy reciprocal similarity method. The results showed that this model is suitable for simulating changes in periods of less than 15 years and patches with areas greater than 25 hectares. The model was run for 15 years, beginning with the year 2014. The results for the study area predict that settlement areas will expand; agricultural land, rangeland and barren areas will decline; and forests will remain unchanged until 2029.
\end{abstract}

Keywords: simulation, cellular automata, land use/ cover change, land use planning, remote sensing, GIS.

\section{Introduction}

The efficient use of natural resources with human-made extensions can produce sustainable development. This concept is necessary for conservation, remediation and the extension of suitable structures and functions for environmental managers and policy makers (Pourebrahim et al. 2011). Also, the ecological security pattern of the land use has an important role in protecting the urban ecological environment (KwadwoNti 2013; Yuanjing et al. 2015). Quantitative land use/land cover change information is one of the most important needs in landscape planning (Alphan, Guvensoy 2016). Although the terms land use and land cover are definitely related, they are also conceptually different. Many researchers do not agree with this distinction and interchangeably employ these terms (Gregorio, Jansen 2005; Fisher, Unwin 2005; Cheng, Masse 2003). Although the definitions of land cover and land use are distinct, they have an intricate relationship (Alphan, Derse 2013). For example, a land-cover type grass can exist in many land uses, such as built-up areas, parks, and croplands. However, only a few regions of homogenous land use have a single land cover; for instance, settlements may have grass, shrubs, trees and buildings as land cover. In addition, a parcel of land cover can have multiple land uses; a planted forest may be used for hiking, trekking, hunting and grazing (Pourebrahim, Mokhtar 2016).
A model refers to a "simplified representation of a system at some particular point in time or space intended to promote understanding of the real system," whereas "simulation is the manipulation of a model in such a way that it operates on time or space to represent it, thus enabling one to perceive the interactions that would not otherwise be apparent because of their separation in time or space" (Bellinger 2004).

DINAMICA EGO is software that simulates landscape or LUC dynamics using cellular automata (CA), an agentbased model (ABM) and statistical approaches to produce changes in spatial patterns. Mas et al. (2007) and KwadwoNti (2013) compared selected LUC change models with respect to the amount of estimated change, the allocation of changes, the reproduction of change patterns, model validation and advanced simulations and concluded that the models that were evaluated by DINAMICA EGO were the most sophisticated models.

CA, which comprise mathematical models for simulating complex natural systems, enable spatio-temporal experiments to be undertaken and contain large numbers of simple and similar components with local interaction (Wolfram 1984). The cell space on which a CA operates can be considered as equivalent, in a LUC class sense, to an environment, a landscape, or a territory. The cell space in CA is assumed to be both regular in structure

*Corresponding author. E-mail: sh_pourebrahim@ut.ac.ir 
and infinite in extent. At any given time, the CA cells in a LUC have a discrete state, such as forest or non-forest or any of the land use classes (Kamusoko, Gamba 2015). Each cell in CA is surrounded by adjacent neighborhood cells. In CA, transition rules govern the state and evolution of a cell at any given time. These rules are typically and synchronously applied and can change the state of cells according to their individual state and the state of neighborhood cells (Benenson, Torrens 2004).

Map comparison is the most prevalent method for the qualitative and quantitative validation of LUC change models. Map comparison provides a simple comparison of simulated maps with observed/reference maps to measure the similarity between two maps. Numerous mathematical methods are utilized by LUC change modelers to quantify the similarity of maps, such as the cell-by-cell kappa and fuzzy set map comparisons (Visser 2004; Verburg et al. 2006).

Hagen (2003) developed a method for applying fuzzy set theory (known as kfuzzy), considering the fuzziness of location and LUC class/category within a cell vicinity. The method produces a map that specifies the degree of similarity, which ranges in 0-1 for each cell. Soares-Filho et al. (2009) modified the method of Hagen by employing an exponential decay function that utilizes distance to weight the cell state distribution around the core cell and named it Reciprocal Similarity.

In this research, the cellular automata method was employed to simulate the changes in five land use/ cover levels in Karaj City, including settlement, agricultural, rangeland, forest and barren areas. By validating the model and results, the final model was rearranged and the simulation was processed.

\section{Material and methods}

\subsection{Study area}

Karaj City encompasses an area of 174 square kilometers and is located on the southern slopes of the Alborz Mountains in West Tehran. The location of study area is presented in Figure 1. The average elevation of the city is 1,320 meters above sea level. The highest temperature during the warm months of the year is approximately $40{ }^{\circ} \mathrm{C}$ above zero, whereas the lowest temperature during the cold months of the year is $11{ }^{\circ} \mathrm{C}$ below zero. The average

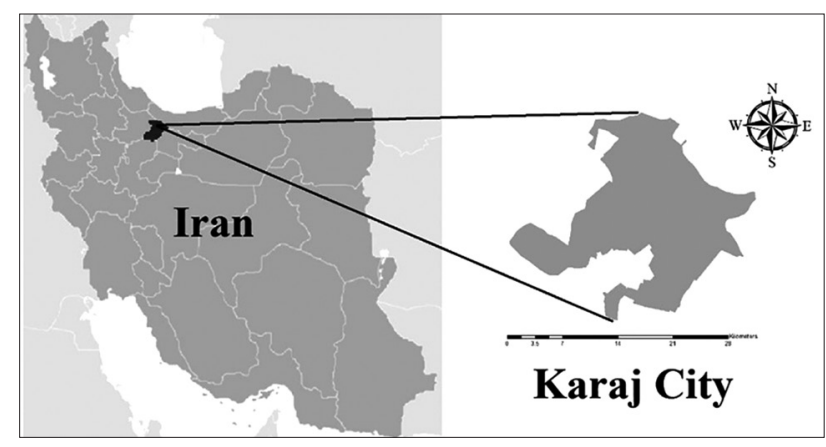

Figure 1. Location of study area annual rainfall is $170 \mathrm{~mm}$, and the dominant wind direction is North-East (Ministry of Roads and Urban Development of Iran 2011).

\subsection{Data set}

The data employed in the model are divided into two main categories: LUC maps and ancillary maps. Ancillary maps are divided into the following two categories: static and dynamic variables. Static variables remain unchanged in all stages of the implementation model, whereas dynamic variables change their status at each stage of the implementation model. In this study, based on the literatures a total of 12 variables were employed: seven static variables and five dynamic variables. The static variables included elevation, slope, aspect, soil salinity, soil texture, distance from rivers, and distance from roads. The dynamic variables included distance from the LUC classes. Maps that depicted soil salinity and soil texture, elevations, slopes, aspects, rivers and roads were prepared using data from the Iranian National Cartographic Center and the National Atlas of Iranian Deserts (Zehtabian 2012). Dynamic maps were created by the DINAMICA EGO software during the modeling process.

LUC maps were prepared from satellite imagery that encompassed the time period from 1985 to 2014 using Landsat TM and ETM + sensors. Images for the three pre-processing, processing and post-processing stages were obtained, and different LUC classes were extracted to ensure that all layers utilized the same coordinate system, projection unit and size of cells (Makhdoom et al. 2001). The properties of all maps in this study are presented in Table 1. The LUC classes in the study include settlement, agricultural, rangeland, forest and barren areas.

Table 1. Map properties of the research

\begin{tabular}{|l|l|}
\hline \multicolumn{1}{|c|}{ Properties } & \multicolumn{1}{c|}{ Values } \\
\hline File type & tiff \\
\hline Cell size & $30 \times 30 \mathrm{~m}$ \\
\hline Columns & 882 cells \\
\hline Rows & 1045 cells \\
\hline Projection system & WGS84-UTM39N \\
\hline No data & -1 \\
\hline
\end{tabular}

\subsection{Methodology}

The study was divided into two stages. In the first stage, a model was developed to simulate LUC changes in the study area. In the second stage, the model considered the results of the first stage of reform were employed in the final simulation. The first stage was divided into two parts. The first part is referred to as the calibration because the current situation is based on existing data and provided a general model. In the second part, which is referred to as the validation, the results of the model for a period of time is compared with the results observed at the same time; based on the results, the model was 
modified and optimized and the final simulation model was employed to complete the process. Additionally, the model validation study was performed in two stages: in the first stage of the validation, the optimized model was based on the results; in second stage, the model was tested and verified.

In this study, DINAMICA EGO software was employed to create models and run simulations at all stages. In the first stage, a LUC change model was calibrated using the historical data of the area in the period 1985-1991. The time period of the models of the LUC changes is determined depending on the type of data. Map classes employ a regular grid of cells, in which each cell is automatically assigned to an appropriate value for the LUC class. After preparing the data, a transition matrix based on the Markov Chain must be constructed for the time period from 1985 to 1991. It comprises the results of the calculation of the Markov time series between the primary LUC map and the secondary LUC map.

In the second stage, which employs the transition matrix, the matrix coefficient WoE was calculated based on a Bayesian method and the probability of transition from one class to another class. This study aimed to investigate the changes in coverage and usage among five classes; a total of 20 different transition modes were defined. The DINAMICA EGO software divides the WoE coefficient range for each variable for each transition into intervals and verifies the effectiveness of each variable.

In the third stage, a probability map was constructed at each stage of simulation using the matrix coefficient WoE and using the previous LUC map; the simulation for the current stage was performed and the results of a new LUC map were stored.

Simulated and observed maps were compared on the basis of reciprocal similarity and a fuzzy analysis approach and minimum and maximum similarity between them was determined. First, a moving window with variable dimensions moved on the maps in odd numbers between 1 and $\mathrm{n}$ and the patterns and structures within the map were compared. In this study, a model that was recalibrated by the validation results and simulation was obtained in 2000. Second, by considering the model results, the simulation executed to 2014. Last, the results were validated using the outcomes and the simulated maps in 2000 and 2014.

\section{Results}

In first stage of simulation, a transition matrix between two LUC maps for 1985 and 1991 was calculated based on a Markov chain for a six-year period. The parameters of this matrix are listed in Table 2. The table value for each cell is equivalent to the probability of the conversion from the corresponding row to the corresponding column. The cells of the table, which have the possibility of zero (i.e., the transfer did not occur in the specified time interval), have been identified with dashes.

Due to the anticipated transition matrix, the WoE coefficient matrix was calculated and the significance was assessed according to the significant column for each transition variable as shown in Figure 2. The variables that did not affect the model were removed, and the matrix coefficient WoE was recalculated and stored.

In this study, the presence or absence of a correlation between variables was evaluated based on the Uncertainty Information Joint method, and variables that for which the correlation was higher than 5.0 were identified as independent variables. The results of this step are shown in Table 3. In each transition, only one of the correlated variables (variables specified in the last column of Table 3) remained in the model. The remaining variables were excluded from the model, and the final matrix coefficient WoE was recalculated.

Using the final WoE matrix, the first stage of the simulation was performed. Because the initial LUC map depicted the LUC in 1985 and the last LUC map in 2000 was employed for calibration, the model was repeated 15 times

Table 2. Transition matrix for a period of six years between 1985 and 1991

\begin{tabular}{|l|c|c|c|c|c|}
\hline & $\begin{array}{c}\text { Settle- } \\
\text { ments }\end{array}$ & $\begin{array}{c}\text { Agricul- } \\
\text { tural } \\
\text { Area }\end{array}$ & $\begin{array}{c}\text { Range- } \\
\text { land }\end{array}$ & Forest & $\begin{array}{c}\text { Barren } \\
\text { Area }\end{array}$ \\
\hline $\begin{array}{l}\text { Settle- } \\
\text { ments }\end{array}$ & $\star$ & 0.0071 & 0.0094 & 0.0014 & 0.0021 \\
\hline $\begin{array}{l}\text { Agricul- } \\
\text { tural Area }\end{array}$ & 0.0398 & $\star$ & 0.0520 & 0.0050 & 0.0036 \\
\hline Rangeland & 0.0050 & 0.0035 & $\star$ & 0.0001 & 0.0307 \\
\hline Forest & 0.0001 & 0.1122 & - & $\star$ & - \\
\hline $\begin{array}{l}\text { Barren } \\
\text { area }\end{array}$ & 0.0604 & 0.0014 & 0.0312 & - & $\star$ \\
\hline
\end{tabular}

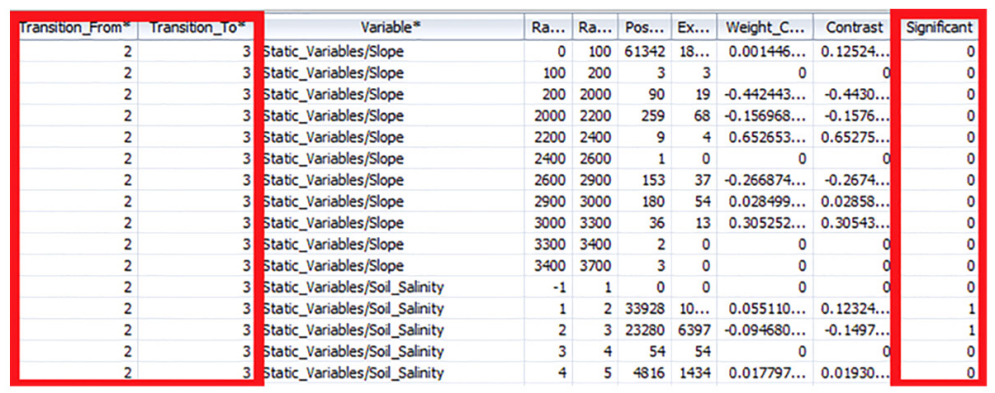

Figure 2. Summary of some of the variables for which their influence on the transition has not been approved 
Table 3. Results of the correlations among variables using the Uncertainty Information Joint method

\begin{tabular}{|l|l|l|l|l|}
\hline $\begin{array}{c}\text { Tran- } \\
\text { sition }\end{array}$ & \multicolumn{1}{|c|}{$\begin{array}{c}\text { First } \\
\text { variable }\end{array}$} & $\begin{array}{c}\text { Second } \\
\text { variable }\end{array}$ & $\begin{array}{c}\text { Correlation } \\
\text { value }\end{array}$ & $\begin{array}{c}\text { Removed } \\
\text { variable }\end{array}$ \\
\hline $1->3$ & Soil salinity & $\begin{array}{l}\text { Soil } \\
\text { texture }\end{array}$ & 0.54 & Soil salinity \\
\hline $1->4$ & Soil salinity & $\begin{array}{l}\text { Soil } \\
\text { texture }\end{array}$ & 0.56 & Soil salinity \\
\hline $1->5$ & Soil salinity & $\begin{array}{l}\text { Soil } \\
\text { texture }\end{array}$ & 0.57 & Soil salinity \\
\hline $2->1$ & Soil salinity & $\begin{array}{l}\text { Soil } \\
\text { texture }\end{array}$ & 0.53 & Soil salinity \\
\hline $2->4$ & Soil salinity & $\begin{array}{l}\text { Soil } \\
\text { texture }\end{array}$ & 0.54 & Soil salinity \\
\hline $2->5$ & Soil salinity & $\begin{array}{l}\text { Soil } \\
\text { texture }\end{array}$ & 0.54 & Soil salinity \\
\hline $3->1$ & Soil salinity & $\begin{array}{l}\text { Soil } \\
\text { texture }\end{array}$ & 0.54 & Soil salinity \\
\hline $3->5$ & Soil salinity & $\begin{array}{l}\text { Soil } \\
\text { texture }\end{array}$ & 0.56 & Soil salinity \\
\hline $4->3$ & Soil salinity & $\begin{array}{l}\text { Soil } \\
\text { texture }\end{array}$ & 0.55 & Soil salinity \\
\hline $5->2$ & Soil salinity & $\begin{array}{l}\text { Soil } \\
\text { texture }\end{array}$ & 0.55 & Soil salinity \\
\hline $5->3$ & Soil salinity & $\begin{array}{l}\text { Soil } \\
\text { texture }\end{array}$ & 0.54 & Soil salinity \\
\hline
\end{tabular}

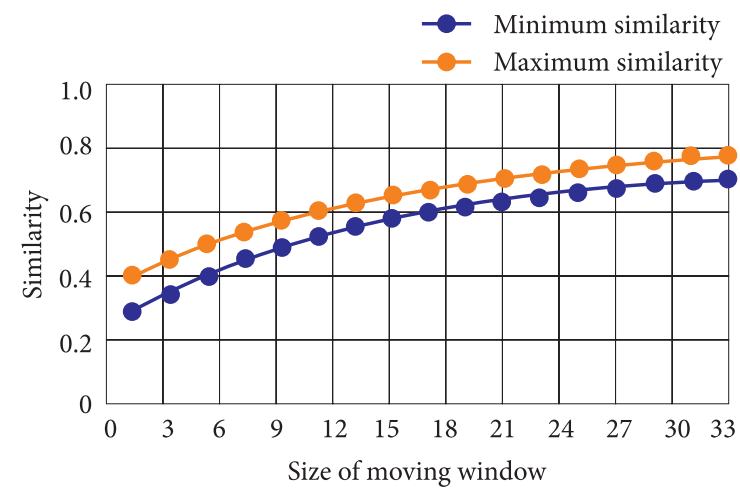

Figure 3. Maximum and minimum of similarity between simulated map and observed map in Karaj City in 2000

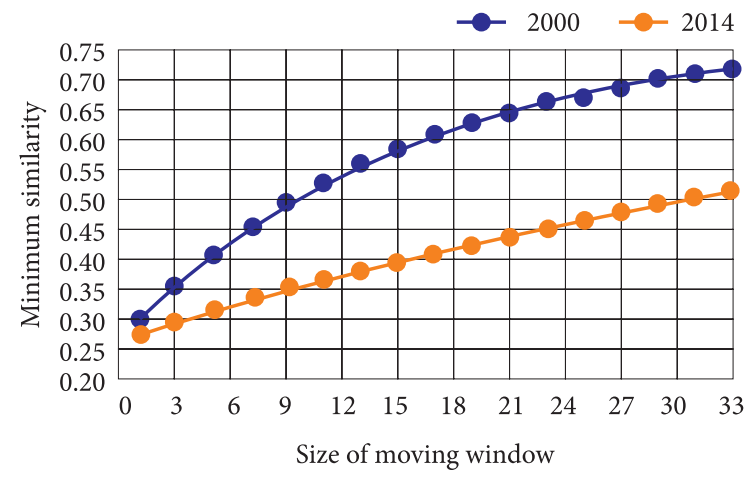

Figure 4. Comparison of the simulation results of the LUC change model for years 2000 and 2014 and changes from 1985 to 2000 in Karaj City were simulated. The simulated map of LUC in 2000 was considered to be output for the first part.

The validation between the simulated map and the observed map in 2000 was executed by the reciprocal similarity method. In this method, the size of the moving window was modified from 1 to 33 . The results of this step are shown in Figure 3.

Based on the results, an increasing trend in the similarity between the observed LUC map and the simulated LUC map in Karaj City in 2000 is commensurate with an increase in the size of the moving window. In the analysis of the calibration and validation of the model, the charts and the results with the lowest similarity were utilized to ensure the greatest accuracy of the results.

After the first stage of simulation, a simulation process was performed for the time period 1985-2014 for 29 years to assess the validity of the model and compare the results with reality, as the second stage of the simulation process. The results were validated for 2000 and 2014 with the observed data and by the reciprocal similarity method to assess model accuracy. The results are presented in Figure 4.

As shown in Figure 4, the lowest similarity between the observed data and the simulated data increases in both cases by increasing the size of the moving window. This means that landscape-scale studies (that consider patches) provide more accurate results. Additionally, the comparison of the results of the validation for 2000 and 2014 indicate that for all values of the size of the moving window, the results for 2000 for a period of 15 years is significantly more accurate and reliable compared with the simulation results for a period of 29 years (results for 2014). The findings confirm the validity of the results of the model for a period of 15 years and for patches with an area greater than 32 hectares.

To verify the model's sensitivity to the number of ancillary variables in the model, a calibration of the model was implemented using only two variables, including the DEM map, which was employed as a static variable, and the distance to settlements map, which was employed as a dynamic variable. Then, the simulation was re-executed using a new model for the time period 1985-2000 for 15 years. The results were simultaneously compared with observed data by the reciprocal similarity method. The result is displayed in Figure 5.

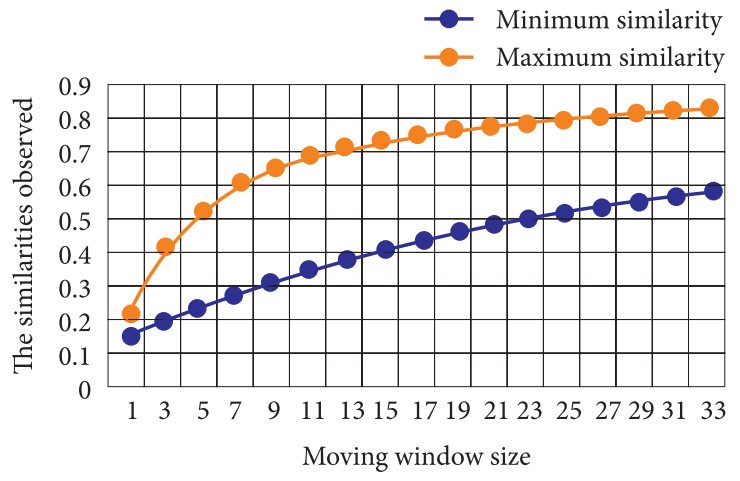

Figure 5. Minimum and maximum similarity between observed map and simulated LUC map of Karaj city in 2000 using sensitivity analysis 
The results showed that a reduction in the number of model variables generates a reduction in the similarity between the simulated map and the observed map. The two maps from the original model and the model using the sensitivity analysis were compared cell-by-cell using reciprocal similarity. The results indicate that the minimum similarity between the two maps is 0.32 and the maximum similarity is 0.36 with a difference of approximately $65 \%$ between the results of original model and the results of the model using the sensitivity analysis. Because the only difference between these two models was the number of ancillary variables, the results conclude that the model is sensitive to the number of ancillary variables.

Table 4. Results for Karaj LUC changes from 2014 to 2029 (in percent)

\begin{tabular}{|l|c|c|c|c|c|}
\hline & $\begin{array}{c}\text { Settle- } \\
\text { ments }\end{array}$ & $\begin{array}{c}\text { Agricul- } \\
\text { tural } \\
\text { Area }\end{array}$ & $\begin{array}{c}\text { Range- } \\
\text { land }\end{array}$ & Forest & $\begin{array}{c}\text { Barren } \\
\text { Area }\end{array}$ \\
\hline 2014 & 44.98 & 10.21 & 26.52 & 0.25 & 18.04 \\
\hline 2019 & 51.60 & 7.52 & 28.05 & 0.21 & 12.62 \\
\hline 2024 & 54.17 & 5.18 & 27.88 & 0.47 & 12.30 \\
\hline 2029 & 55.76 & 3.98 & 28.33 & 0.55 & 12.38 \\
\hline
\end{tabular}

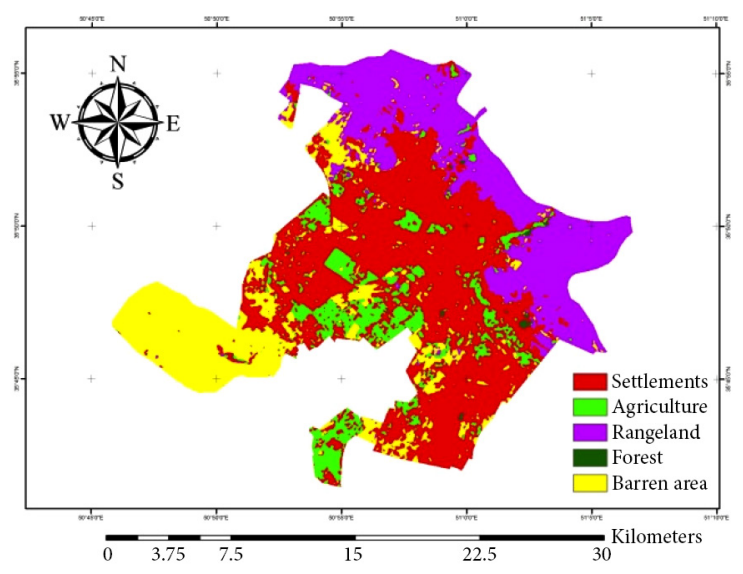

Figure 6. Observed LUC map in year 2014

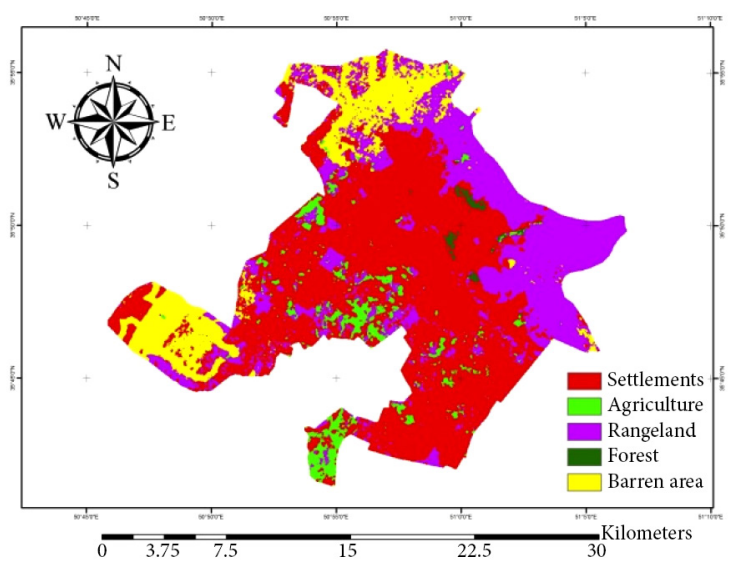

Figure 8. Simulated LUC map in year 2024
In the second stage of simulation, the process was performed for Karaj City for a period of 15 years, beginning in 2014; the results are presented in Figures 6-9 and Table 4.

\section{Discussion}

The importance of land use change detection has led to the development of many decision support systems for land use planners (Mcclean 1995). Based on the results, simulation with the cellular automata method was determined to be an appropriate method for assessing LUC changes as it is gaining recognition as one of the key derivers of global environmental changes (Ramachandra et al. 2014). Determining of rate and shape of changing in environmental structure has an important role for environmental protection. Converting land to urban and residential area and deforestation are associated with soil erosion and increasing the frequency and severity of floods. By monitoring the derivers and evaluating the impacts, decision-makers and conservation planners can find optimal solutions that describe sustainable development (Kucas 2010) Human-induced changes in land use often result in habitat fragmentation and loss. Simulation of land use

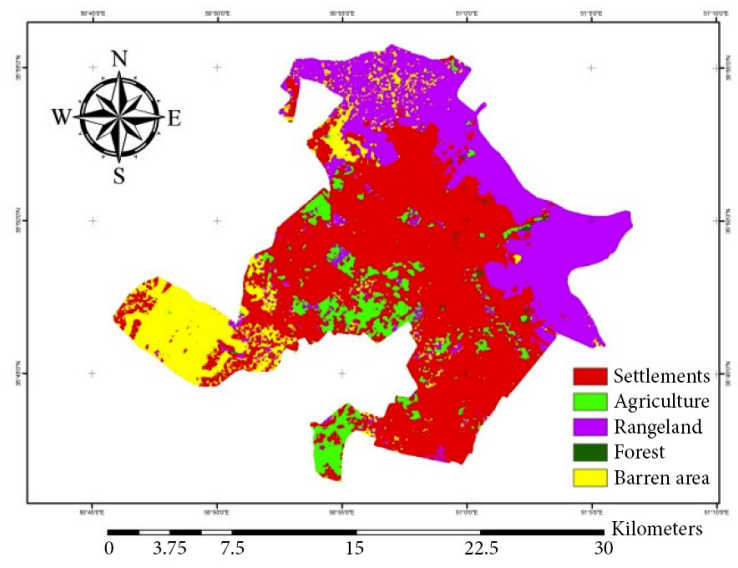

Figure 7. Simulated LUC map in year 2019

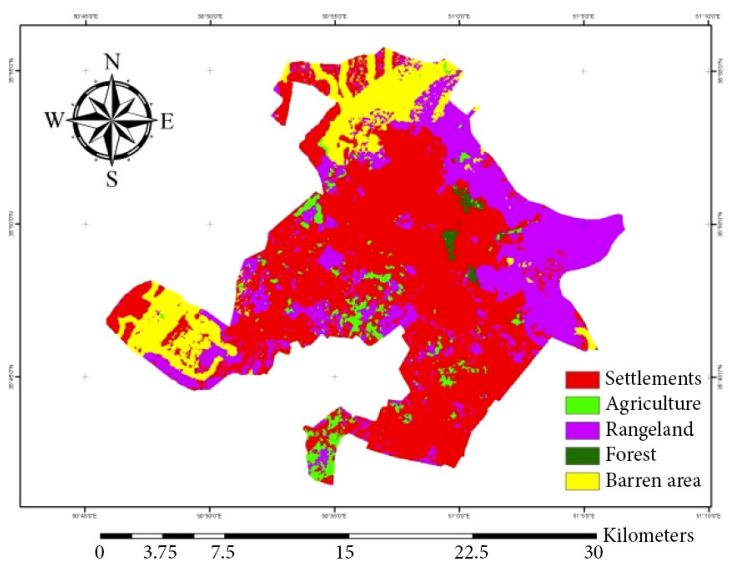

Figure 9. Simulated LUC map in year 2029 
change can help to environmental protection even in predicting and measuring the connectivity between adjacent habitats (Torre et al. 2015).

In this study, a Markov chain as the transition matrix result affected the model at different times. For each transition, the probability of inter transitions between LUC classes were determined based on a stateless Markov chain. According to the results, the greatest value (0.1122) was obtained for the transition from the forest class to the agricultural area class, and the lowest values (0.0001) were obtained for the transition from the forest class to the settlements class and from the rangeland class to the forest classes. However, the highest value of the transition was obtained for the transition from the forest class to the agricultural area class. Due to the small number of forests in the study area and certain variables such as height and slope that have affected these transitions, the results of the transition matrix are consistent with the results of the validation. According to the results of the final implementation model, the use of a Markov chain in the computational kernel of the model has produced results that resemble reality. Some researchers employed a Markov chain in the kernel of their cellular automata model and confirmed that the results obtained by this method can improve the efficiency of the model (Tang et al. 2007; Zare-Garizi et al. 2011; Soares-Filho et al. 2012; KwadwoNti 2013).

The validation method in this research is the reciprocal similarity method, which combines the accuracy of a kappa coefficient analysis and a fuzzy method. In this method, areas with the same size were compared using two maps and the difference between them related to their parent maps was determined. However, the data validation for the final simulation and the comparison with the corresponding data will be employed to assess and validate the model. Both procedures were performed in this study. In this study, structural similarities between the observed data and the simulated data for regions with areas that range from 900 square meters to 98 hectares were analyzed. The results suggest that the similarity between the observed map and the simulated map for the 15-year period increases with an increase in the size of the moving window. The results are consistent with reality for regions with an area of 900 square meters with a minimum possibility of $30 \%$, for regions with an area of 29 hectares with a minimum possibility of $60 \%$ and for regions with an area of 98 hectares with a minimum possibility of $70 \%$. Reciprocal similarity and fuzzy analysis has been recommended for the validation phase (Ahadnejad-Roushti et al. 2011; Sheng et al. 2012). Their results also confirm the high performance of the fuzzy analysis method for validating the results of the simulation.

Based on the results for the study area for 2014-2029 in terms of the estimated extent of the LUC classes, settlements will experience a growth of approximately $10 \%$, agricultural area will experience a reduction in growth of approximately $5 \%$, forests will experience a small increase of $0.3 \%$; barren areas will experience a decrease of approximately $6 \%$ and rangeland will experience minimal fluctuation. The largest amount of physical development will occur for settlements. In some areas, agricultural land will be converted to rangeland and agricultural land will be converted to settlements. In the northern part of Karaj City, settlements will be converted to rangeland; settlements will develop into barren areas in the southern part of Karaj City. The forest class will remain almost intact and will be developed in some areas of the city. Studies by Sakieh (2013) revealed that the land in the southern region and the land near the settlements are utility zones for the construction of urban structures, which confirms the results obtained in this study.

\section{Conclusions}

Based on the simulations performed in Karaj City, the settlement class exhibited the most development during the 15-year period 2014-2029. These areas extend to agricultural land, rangeland and barren areas. These results can be interpreted as future expansion of the settlements in Karaj City is not dependent on the quality of the surrounding terrain. The findings also indicate that the development of settlements in the southern half of the city is expected to surpass the development of other areas in the future. Given that agricultural land is more prevalent in the southern half of the city, this finding can be considered to be an alarm for urban planners and managers. Based on the results of this study, subsequent studies that employ socio-economic variables and maps and the use of these variables in a model are recommended. Using maps with different resolutions, the simulation model is independent of the cell size of maps. Regarding the criticism of the transition matrix calculation, the DINAMICA EGO software should be amended to enable the use of calculation tools that employ a larger number of maps to calculate a transition matrix. Because the variables employed in the model were limited to the border of Karaj City, the impact of the variables on the simulation was not considered. Studies of the area around the border of Karaj City are recommended to enable a comparison with the results of this research. Given the importance of future studies in the planning process, the results of these studies can be applied to the planning process and management to evaluate their effectiveness in practice.

\section{Acknowledgement}

This study was supported by University of Tehran and Department of Environment (Alborz Province) under the grant number 7314850/1/1 and project number 952/5/298.

\section{References}

Ahadnejad-Roushti, M.; Zolfi, A.; Shokripour, H. 2011. Assessing and predicting physical urban growth using multi time satellite images and GIS (case study: Ardebil city 1984-2022), Journal of Environmental Assessment 15: 107-124.

Alphan, H.; Derse, M. A. 2013. Change detection in Southern Turkey using normalized difference vegetation index (NDVI), 
Journal of Environmental Engineering and Landscape Management 21(1): 12-18.

https://doi.org/10.3846/16486897.2012.663091

Alphan, H; Guvensoy, L. 2016. Detecting coastal urbanization and land use change in southern Turkey, Journal of Environmental Engineering and Landscape Management 24(2): 97-107. https://doi.org/10.3846/16486897.2015.1113976

Bellinger, G. 2004. Modeling \& simulation: an introduction [online], [cited 6 January 2015]. Available from Internet: http:// www.systems-thinking.org/modsim/modsim.htm

Benenson, I.; Torrens, P. M. 2004. Geosimulation: Automata-based modelling of urban phenomena. West Sussex: Wiley. $312 \mathrm{p}$. https://doi.org/10.1002/0470020997

Cheng, J.; Masser, I. 2003. Urban growth modeling: a case study of Wuhan City, PR China, Landscape and Urban Planning 62: 199-217.

https://doi.org/10.1016/S0169-2046(02)00150-0

Fisher, P.; Unwin, D. J. 2005. Re-presenting GIS. Wiley, London. $296 \mathrm{p}$.

Gregorio, A. D.; Jansen, L. J. 2005. Land cover classification system: Classification concepts and use manual [online], [cited 7 January 2015] Available from Internet: http://www.fao.org/ gtos/doc/ECVs/T09/ECV-T9-landcover-ref25-LCCS.pdf

Hagen, A. 2003. Fuzzy set approach to assessing similarity of categorical maps, International Journal of Geographical Information Science 17(3): 235-249.

https://doi.org/10.1080/13658810210157822

Kamusoko, C.; Gamba, J. 2015. Simulating urban growth using a random forest-cellular automata (RF-CA) model, ISPRS International Journal of Geo-Information 4(2): 447-470. https://doi.org/10.3390/ijgi4020447

Kucas, A. 2010. Location prioritization by means of multicriteria spatial decision-support systems: a case study of forest fragmentation-based ranking of forest administrative areas, Journal of Environmental Engineering and Landscape Management 18(4): 312-320.

https://doi.org/10.3846/jeelm.2010.36

KwadwoNti, I. 2013. geospatial process modelling for land use cover change: $\mathrm{PhD}$ thesis. Auckland University of Technology. $216 \mathrm{p}$.

Makhdoom, M.; Darvishsefat, A. A.; Jafarzadeh, H.; Makhdoom, A. 2001. Environmental assessment and planning by using GIS. University of Tehran press. 304 p. (in Persian).

Mas, J.; Paegelow, M.; De Jong, B.; Masera, O.; Guerrero, G.; Follador, M.; Olguin, M.; Diaz, J. R.; Castillo, M. A.; Garcia, T. 2007. Modelling tropical deforestation: a comparison of approaches, in $32^{r d}$ Symposium on Remote Sensing of Environment, June 2007, San José, Costa Rica. 3 p. en CD.

https://halshs.archives-ouvertes.fr/halshs-01063568

Mcclean, C. J. 1995. Land use planning: a decision support system, Journal of Environmental Planning and Management 38: 77-92.

https://doi.org/10.1080/09640569513129

Ministry of Roads and Urban Development of Iran. 2011. Strategic and structural planning for Karaj city. 194 p.

Pourebrahim S.; Mokhtar, M. B. 2016. Conservation priority assessment of the coastal area in the Kuala Lumpur mega-urban region using extent analysis and TOPSIS, Environmental Earth Science 75: 348-355.

https://doi.org/10.1007/s12665-016-5276-3
Pourebrahim, S.; Hadipour, M.; Mokhtar, M. B. 2011. Integration of spatial analysis for land use planning in coastal areas; case of Kuala District, Selangor, Malaysia, Landscape and Urban Planning 101(1): 84-97.

https://doi.org/10.1016/j.landurbplan.2011.01.007

Ramachandra, T. V.; Bharath, S.; Bharath, A. 2014. Spatio-temporal dynamics along the terrain gradient of diverse landscape, Journal of Environmental Engineering and Landscape Management 22(1): 50-63.

https://doi.org/10.3846/16486897.2013.808639

Sakieh, Y. 2013. Determining of sustainable development index for Karaj city based on urban growth simulation and environment capability: MSc thesis. Faculty of natural resources, University of Tehran. $152 \mathrm{p}$.

Sheng, J.; Qing, G.; Chun-yu, W.; Bei, L.; Xiao-dong, L.; Guangming, Z.; Zhong-xing, Y.; Jie, L. 2012. Ecological suitability evaluation for urban growth boundary in red soil hilly areas based on fuzzy theory, Journal of Central South University 19: 1364-1369. https://doi.org/10.1007/s11771-012-1151-x

Soares-Filho, B.; Lima, L.; Bowman, M.; Viana, L. 2012. Challenges for low-carbon agriculture and forest conservation in challenges for low-carbon agriculture and forest conservation in Brazil. Inter-American Development Bank. 40 p.

Soares-Filho, B.; Rodrigues, H.; Costa, W.; Schlesinger, P. 2009. Modeling environmental dynamics with dinamica EGO. Belo Horizonte. $116 \mathrm{p}$.

Tang, J.; Wang, L.; Yao, Z. 2007. Spatio-temporal urban landscape change analysis using the Markov chain model and a modified genetic algorithm, International Journal of Remote Sensing 28(15): 3255-3271. https://doi.org/10.1080/01431160600962749

Torre, R. D.; Jimenez, M. D.; Ramirez, A.; Mola, I.; Casado, M. A.; Balaguer, L. 2015. Use of restoration plantings to enhance bird seed dispersal at the roadside: failures and prospects, Journal of Environmental Engineering and Landscape Management 23(4): 302-311. https://doi.org/10.3846/16486897.2015.1079529

Verburg, P. H.; Kok, K.; Pontius, R. G.; Veldkamp, A. 2006. Modeling land-use and cover change, in Land-use and land cover change: local processes and global impacts. Springer-Verlag Germany, Berlin, 117-135.

https://doi.org/10.1007/3-540-32202-7_5

Visser, S. 2004. The map comparison KIT: methods, software and applications. Bilthoven. 127 p.

Wolfram, S. 1984. Universality and complexity in cellular automata, Physica 10: 1-35. https://doi.org/10.1016/0167-2789(84)90245-8

Yuanjing, Zh.; Binyang, Y.; Ashraf, M. A. 2015. Ecological security pattern for the landscape of mesoscale and microscale land: a case study of the Harbin City center, Journal of Environmental Engineering and Landscape Management 23(3): 192-201. https://doi.org/10.3846/16486897.2015.1036872

Zare-Garizi, A.; Sheykh, V.; Sadaldin, A.; Mahini, A. 2011. Spatio-temporal simulation of forest changes in Chehel Chay basin of Golestan province using combination of cellular automata and Mrkov chain, Journal of Iranian forest research 20(2): 273-285.

Zehtabian, Gh. 2012. National atlas of Iranian desertification. University of Tehran. 255 p. 